\title{
The Obstacles Facing the Privatization of Manufacturing Industries and Economic Reform in Kurdistan Region/Iraq
}

\author{
Razzaq O. Mustafa (Assistance Prof. Ph.D)
}

Head of Industrial Zones in Kurdistan Region, Ministry of Trade and Industry

abdulrazzaqnawandaie@gmail.com

\section{ARTICLE INFO}

\section{Article History:}

Received: $28 / 9 / 2020$

Accepted: $30 / 11 / 2020$

Published: Winter 2021

Keywords: Economic

Reforms, Private Sector,

Privatization, Industrial

Development,

Openness,

Manufacturing

Industries.

Doi:

10.25212/lfu.qzj.6.1.31

\section{ABSTRACT}

The development period pre-2003 is characterized by a lack of resources especially financial resources. In contrast after 2003 , the economy has rapidly been modernized by the inflow of oil revenues and the promotion of private sector, capital investment and FDI development and privatisation. Government market intervention is minimal, and the economy has become open, liberal and the private sector has operated effectively. The inflation and wages increased and the corruption expansion have deteriorated the competitiveness and development of local industrial production.

Meanwhile, in order to increase the possibility of success in the implementation of new law of investment (No.4 in 2006) in Kurdistan Region (KR), it should be focused on the investment of infrastructure in KR. However, here raise some questions, has $\mathrm{KR}$ a relatively suitable investment climate for privatization in accordance with legal and constitutional safeguards?

In plus, the public manufacturing industries was loser and it did not work any treatment only disposal through sale, due to a complex bureaucratic which includes many of the laws, legislation and instruction, and many of the administrative constraints. That prevent the advancement opportunities and suppress quick response, losing of the property of sustainability, and the governmental administration economically/ financially, particularly time and effort wasting, and the administrations in public plants have been 
addicting in supporting, particularly on international subsidies and protection. So, are there economic reform in KR?

\section{INTRODUCTION}

In the light of the current reality of KR economy, the reliance on the style of privatization as a way to solve these worsening economic crises is suffered by the KR economy must take into account the privacy KR economically, politically and socially. Especially, the economic environmental which is characterized disfunction, instability, declining the role of PS, the weakness of its competitiveness in the local market by virtue of economic openness to the rest of the world's countries, the liberalization of the trade fields, and the invasion of the goods and foreign goods to the Kurdish market. For this point of view, before beginning the privatization process, should be the presence of responsible party for the privatization process that has considerable expertise in this area, should be impartial, the conduct of the economic studies to evaluate the efficiency of projects and administering of institutions. More importantly, should be carried out privatization gradually through the stages of a transparent and work to establish institutions of a developed economic, as well as the development of various aspects of the legislation on the business sector such as property rights law, corporate law and competition law.

But the question of attracting this type of investment into KR requires the availability of necessary infrastructure and institutions, ease of administrative and implementation procedures and the financial, tax transactions, and presence of a banking system that works well under the market mechanism. It is worth noting here, the local investment in KR depends on oil revenues, which represents the oil the main financial resource of the state, especially since Iraq has been placed the second largest reserve in the world. Therefore, it could be said that the economic future of KR in a manner associated with significant of the investments volume that performs and the other is based mainly on the level of future oil revenues. 
The developmental policies in KR during the period 1991-2003 characterized very sluggishly due to the political and social reasons, in addition, to the lack of centralized common regulatory, as well as two crippling blockades on KR. During the period 20032011, Kurdish administration has begun planned steps toward economic growth and the provision of goods and services by high social values to the population and improvement in infrastructure, such as improving the level of health and education, constructing roads, transportation, rebuilding the destroyed villages, and providing them the various supports.

\section{Question, Hypothesis and Aim of Research:}

As it is seen, the Kurdistan region economies suffers from several structural imbalances, and the reasons for this is attributed to the lack of coordination and linkages between the sector in these economies on the level of KR, as well as the absence of common economic policy coordination and strategy. This confirms the role of the state, including the suffering of this sector to the failure of planning and management (bureaucracy and corruption) methods, thus weakened its achievements and varied the problems. The research Question, Hypothesis and Aim are as below:

1. uestions:

- What are the most important problems facing the privatization process in MI's in KR?

- Do the public industrial investments have role in development of KRs' economics?

- Which kind of industrial field requires priority in investments for interest of the national economy?

- Does privatization proceed successfully?

- What are the most important weakness and strengthen point of the privatization process in MI's in KR?

- Does huge and non-limit economic openness constitute a threat on industrial economics in KR?

- Who finances the public and private sector in KR?

- Why the industry sector is not developed given with all attempting of KRG?

2. Hypothesis: The hypothesis of this research are as below: 
- The region faced development threats. Kurdish society by formation of political (government and political leadership) and social (social classes and civil society) faced the development threats. The development orientation is unripe even some of its column is not strong and the culture of administration of the state not been the social awareness.

- Lack of abilities to competitiveness the foreign product.

- The size of financial allocations of this sector and the facilities provided do not fit with the leading role which assigned to KRG as a provider of the process of ED.

3. Aim: It is to:

- Identify the most important industrial-economic achievements goals.

- Analyse the components of industrial growth in KR with an indication of the spatial distribution, to making appropriate recommendation for the areas that utilized and developed in a scientific and sound.

- Analyse and state the relative importance of these projects in invested capital and providing job opportunities, thereby operating the unemployed and production.

- Identifying the advantage and disadvantage of openness and structural economic adjustment.

- Determine what obstacles and problems that obstruct the impact in this activity.

\section{Research Methodology and Structure:}

For more analysing the economic reforms and privatization in $K R$, as well demonstrating the factors and actions impact on weakness of development of MI's in $\mathrm{KR}$, as well as for revealing the KRG industrial investment policy to structure and develop the MI's optimally with the industrial planning characterization in KR. The soft data used the descriptive analytical method for analysing "The factors and actions impact on weakness of development of manufacturing industries in KR". 


\section{List of Abbreviation}

CAGR

FAO

Nations

FDI

GDP

ID

IS

$\mathrm{KR}$

KRG

LSMIS

MI's

$\mathrm{MoCl}$

Mol

MoP

MSMI

M.USD

PS

$R \& D$

RDS

SAP

SME'S

SSMI

SWOT

UNDP

UNICEF

USA

USD

WTO
Compounded Annual Growth rate

Food and Agriculture Organization of the United

Foreign Direct Investment

Gross Domestic Product

Industrial Development

Industrial Sector

Kurdistan Region

Kurdistan Region Government

Large-Scale Manufacturing Industries

Manufacturing Industries

Ministry of Commerce and Industry

Ministry of Industry

Ministry of Planning

Medium-Scale Manufacturing Industries

Million United State Dollar

Private Sector

Research and Development

Regional Development Strategy

Structural Adjustment Programs

Small and Medium-scale manufacturing industries

Small-Scale Manufacturing Industries

Strengths, Weaknesses Opportunities and Threats

United Nation Development Program

United Nations Children's Fund

United State of America

United State Dollar

World Trade Organisation

\section{1: The situation of the manufacturing industries during 1982-2011}

The experience of privatization in industrial sector (after land, agriculture sector) was in most expand volume and according to the existence data and its analyse capabilities, in below supply the most important approaches for transferring the ownership of economic sector which involved to privatization process in KRs' 
experience, as follows: (Meervat Altaie (2014).p.39, and Shiva Damyar and Khodadad Khodadadi Dashtaki(2017), Ministry of Planning(2018))

a. Renting approach: According to the low No.32 in 1986 for organization the procedures of sale and rental of state funds, it is seen the most important public Ml's which involved according to this law.

b. Building, operating and transfer (B.O.T) approach: According to this approach, make an agreement between the state and PS for building and managing the specific projects and for limited period less than 25 years, later transfer the ownership of this project to the state.

C. The approach of Building, Ownership and Operating (B.O.O): KRG used this approach for privatization of the projects carry out the functions of basic services (such as Health, education, communication) which before monopolized by the state for purpose the politic and social more than been economic targets.

After the KRG's orientation to encouraging the PS, it gave opportunity to the PS to establish the centers and particular institution in the field of health, education and communication in the KR since 1993 according to the resolutions and laws passed by Iraqi Kurdistan parliament and the KRG.

d. Sales approach: Depending the resolution 6132 in 26.11.1998 passed in KRG's council of ministers has being sold around 1500 public houses and apartment in different ministries to the citizens dwell in it after 1991 at nominal prices.

\section{1: The privatization history in KR}

The manufacturing privatization in KR divides in three major phases, as:

\subsection{1: First Phase (1982-1990):}

In Iraq, it began in the early 1982 where it was the first rental process from the public enterprises belonging to government to the PS. The privatization in this time related to the economic reform program, which the Iraqi government had begun in the early of 1982 for participation the PS in the economic activities by promulgating some laws and resolutions in the early 1982 and ending to the law No.32 in 1986 titling (The law of buying and rental of public assets).( Facts of Iraq, No.3090, 1986, p.182.) Other resolutions such as resolution number 132 in 1987 related to (the nominal capital 
launching of joint stock companies) as a first step for implementing the reform program titling "February reformist", as well as the law number 774 in 1988 to exempt particular projects in the PS from fees and taxes for specific periods. In addition commercial law number 42 in 1989 for encouraging the PS and its contributing in the commercial activities. However, here, it comes some questions to mind that: what happened in the reality? Does privatization proceed successfully? What are the most important weakness and strengthen point of the privatization process in Ml's in KR?

The public sector has acquired a huge percentage of Ml's in Iraq, particularly in the period 1970-1986, but since the program of "February Reformist" applying in 1988 had privatized Erbil Flour manufacture, For example, which installed in 1978 focusing on buying by public auctioning method according to law 32 in 1986 by total value in buying 285375.3 USD at current prices in 1988, in addition the Erbil poultry manufacture, for example, privatized to Ahmed Ismael in 1988.( Razzaq OTHMAN MUSTAFA, Developing Economies, Evaluation of Manufacturing Industrial Development and a Model for Industrial Development for a Case of Kurdistan Region/Iraq, 2014, p.581.)

\subsection{2: Second phase (1991-2002):}

After the 1991 events had led to full withdrawal of central administration in KR, and formation of Kurdistan Regional Government (KRG), the election of 1992, and resulting the double economic blockade inside of UN and Iraqi government on KR, it has appeared the horizon a set of orientations which trend to the activation of the PS role and privatization.

The applied financially/economically policy portfolio faced in KR has threatened economic stability due to the pressure factors on the aggregated expenditure resulting from increasing governmental expenditure that worked strongly during the role of the expenditure multiplier budget in 1980s and after 2003. However, it has to be mentioned, thereby, the structural imbalances increased and the degree of economic and social inequality among the population deepened, which emptied the fiscal policy of its economic and social content in achieving development goals, even 
do not have a regular and active the target. It is weaker than the degree of effectiveness of public finances in the performance of its functions.( Ministry of Planning and Development Cooperation, 2009, p.50.) The justifications for privatization are:

a. Withdrawal of the Iraqi central government administration in KR and imposed an unfair economic blockade. In addition to the weakness of KRs' financing resources capabilities newly forming in the ruins of collapsing economic sectors, were combined from the objective circumstances which had led to controlling the PS especially in Ml's, and in general on commercial activities (local and foreign trade) and the majority of other sectors, except such governmental service and some public MI's. For KRG's did not rest main role in the commercial in particular and in economic activities in general, while its main dependence had been on the customs duties, certain taxes, fees and a few other resources.

b. The weakness of KRGs' financing capabilities and its capabilities to absorption of most of economic sectors and manage it, as well as lack of any economic policy inside of KRG for supporting the economic activities for the period 1991-2003.

c. Political and militarily competition and civil war in KR for the period 1994-1997 which had led to universal weakness for whole economic sectors resulting of continually stopping and stalled productive Ml's in KR, in addition the weakness of government in management of economic activities.

d. The absence of infrastructure and weaken of financing situation or the weakness of government budget in worst score where it depends to the extent on the ration and the aid of international humanitarian organization. Nevertheless, with that with any support inside of foreign organizations or UN, the KRG attempted to restart or/and re-operating or buying the machineries and equipment's for remaining the public Ml's in this period.

e. The weakness of market activities, lack of central organizational in KR and the existence of two states (Kurdistan Democratic Party(KDP) controlled the state based in Erbil and Patriotic Union of Kurdistan(PUK) controlled the state based in Sulaimany) due to the civil war, increase the unemployment, in particular high rate of disguised unemployment.

f. Continuation of the resolution and laws issued by central government before 1991 continued by the KRG until now with some legal amendments except for other elements pushed the government to allow the PS to work in all economic sectors for the period 1992-2002. As well, applying the privatization programs in 
the MI's that was exposed to losses or the sectors were not allowed for the PS to work on it in previous periods.

\subsection{3: Phase III: after 2003:}

This phase begin by Kurdish federalism's claim inside of Kurdish leaders and political authorities. Despite the existence two states they had build many tasks which imposed during the past years, and had started to them first step to construct a set of functions such as; unifying the two states and strengthening the KRG, building an economic base, attempting to following the planning approach, investment increasing in infrastructure, specification the parties faithful cadres in KRG for constructing an economic base based on market economic, which led to improvement of standard of living in KR. This period characterized by following:( KRG/Ministry of Trade and Industry)

a. Particularly after 1997, the political orientation of KR has oriented toward for allowing the escape for PS and market liberalization and competition and governments department away from some economic field which the PS could work more efficiency on it.

b. The huge capacities for PS and raising the rich class that has capabilities to manage the economic activities better than public sector and capabilities to open the free trade market between each one of Turkey and Iran. Therefore, the PS controlled completely the commercial activities after 2003.

\section{2: The problems and obstacles of the privatization process in manufacturing} industries in KR:

It is clear from MoCl's data that, there are some public manufactures which did not privatize (almost of them were installed in Sulaimany province) lost (-6344407.273) USD in 2011. ( KRG/Ministry of Trade and Industry) Because some of them did not has any revenue and some of them did not has any production except "The ice manufacture in Kefry" which its total revenue does not consider in account on the KRG's budget. It should be mentioned this manufactures despite they did not have production or have a low production while KRG obliged to pay the salaries of 
employees. It should to note the total public manufactures producing just $7 \%$ of them manufactures expenditures and $93 \%$ of them expenditure is an absolute burden on the KRG's budget in 2010.

As all other developing countries in privatization experience, the privatization process has faced the problems and obstacles in applying of privatization program in $\mathrm{KR}$, the main these problems are:

As all other developing countries in privatization experience, the privatization process has faced many problems and obstacles on proper applying program successfully in $\mathrm{KR}$. Thereby, the main roots of these problems are:

a. Lack of legal document and popular supporting for it, despite the existence of KRs' parliament these experiences were not based on particularly laws and legislations for its implementation. Which needs for the purpose of legislation and identify implementing this process in various economic sectors, especially the industrial sector, in order to protect the public interest, but it was based on the personal endeavor and efforts of the supreme authorities in the $\mathrm{MoCl}$ in KRG. It had not issued a special law justifying their necessity, also not the formulas procedural implementation and only adapted to the law No.32 in 1986 titling (The law of buying and rental of public assets).

b. Lack of legal legislation to reducing the problem of unemployment caused by the demobilization huge number of workers and imposed the preconditions on the affiliates of the PS and tenant such projects, as not to be an additional burden on the KRG budget. This is as well as the absence of confidence of employees in public MI's to work in the PS in KR. The public sector was providing them pensions or compensation in the event of exposure to accidents in the task performance, which is not available in the PS in the KR because of the shortcomings of the labor legislation.

c. The privatization has led to dispense of civil service of technical personnel in the areas that shifted from the public to the PS, such as dairy, weaving and cigarette manufactures, they still earn salaries from the KRG without any productivity or benefit from their experiences in the PS.

d. Despite the KRs' political orientation towards liberalization of markets and supporting the PS and privatization; lack of particular board for implementation of 
the privatization process for evaluation of the machineries, determining its value economically-socially-politically, and choosing the appropriate approach and investors, in addition to find the well treatment for surplus employees without happening the disguised unemployment as not to be an additional burden on the KRG budget.

e. The technology obsolescence of machineries and equipment in public Ml's, if it substituted for new technologies that will carry out the huge investment expenses equivalent or equal to installation of new Ml's. Therefore, the absorption of investors toward these manufactures are really difficult without concessional terms.

f. The $\mathrm{MoCl}$ that is implementing body for industrial privatization did not conduct the objective assessment for assets and machineries in public facilities that have been privatized in any way from the approaches of known privatization, and identify the policies and needed conditions to implement the process. Where to be this process is visualizations and syndrome with the KRs' economic, political and social situation to achieve its declared objectives.

g. The transparence and announces are of the other most important affairs of privatization requirement, which the privatization process in KR has lacked them. Where they were some of the processes mentioned between the bilateral on the basis of non-objective (by patronage) and some time without advertising in the media. Some rental privatization based on a personal request made by the tenant person based mainly on personal responsible knowledge, and that was the cause of weak popular support for this process in the KR.

h. The financial and humanitarian capabilities are limited in local PS, as well as the weakness of its technologies capabilities in the evolution and renewal of Ml's. In addition, the KRG has deal in particular with some companies in the PS and give it the priority and monopoly rights to some companies without other companies.

i. The privatization did not provide added-value and surplus revenue for $K R$, where $K R$ could use in other sector useful for society while KR compensated for the loss in public ownership dating back originally to the society.

j. The orientation of PS in KR is toward the rapid profit, that it is the main factors has led to away on LSMI's or the strategic MI's which have an economic and social revenue on long-term for investors and the whole society, too.

k. Lack of stock market in KR which helps to provide the needed capital for large-scale investment as well as transferring some public Ml's for privatizing to private jointstock company which could participated a wide base of citizens where could get a 
popular supporting for the privatization process. Despite the stock market of Baghdad did not have any effect, relation and corporation with KR.

I. Even after the appearance of negative impact on privatization experience in KR including misconducting in the public properties also stopping and returning the contract of some MI's which had privatized, the KRG did not take measures to find the alternatives to the approaches used for privatization. As well as KRG did not take measures to finding the solutions to the difficulties that accompanied them were including unemployment and the huge financial burden, which the KRG's budget has been carrying out it.

$\mathrm{m}$. The majority MI's installed by FAO were SSMI's did not have feasibility study while they have installed just for temporary social-economic target such as creating workforce opportunities, selling the raw material of some manufactures. In addition, to the openness with lack of protection for local Ml's have a negative impact on public Ml's resulting from their inabilities with foreign commodities in terms of prices and quality which led to stopping almost of them without stopping them expenditures, especially the wages and salaries.

In other side, that is right government gave many advantage for privatization and activation to the PS but until now there are some MI's did not privatize and they rest without any production cause they lost them machineries and were been extinct without stopping them expenditures, especially the wages and salaries.

\section{2: Economic reform and structural adjustment in Kurdistan region/Iraq}

After liberalization of KR in 1991 the situation had grant to the Kurds the opportunity to fill the administrative gap (that left by the withdrawal of Iraqi central government) and building the region institutions, including the Parliament Council of Kurdistan and the KRG in 1992, in addition to managing other official and semi-official institutions. Its first steps started for new legislation, all aimed to rebuild the KR and improve the social, health, economic, and political situation, and despite the many obstacles.

\section{1: The waves of economic reform}

Three main waves of economic reform can be identified in the three phases: 


\subsection{1: Phase I: Agricultural and rural reform 1992- 2003:}

It is the phase of KR liberalization, which the party politic made a parliament and KRG, and the government has built the institutions and governmental bodies despite to facing several economic-politic obstacles due to suppose the two clipping blockade (inside of international society (UN) on Iraq and inside of Iraq on Kurdish area in Iraq). The construction and building of school, hospitals, roads ... other services have begun but local internal politic problem, civil war, and non-stable politic in plus external politic entry have a huge impact on delaying the economic development in KR.

The period 1992-2003 could call an initial phase for transition the social system to free market and liberalization of capital which toward to capitalism. Before 2003, due to lack of banking system, there is directly cash circulation that led to inflation and its negative consequences were continued.

KRs' economic reforms began in agriculture at the beginning of 1998, following the upheavals of the international aids such as FAO and UNESCO, and the political revolution in 2003 with falling down of Iraqi regime. Key measures included the leasing of production and encouraging of farmers under the household responsibility system, higher procurement prices for key crops and introduction of KR by NGO's to foreign countries. The reforms led to a surge in agricultural production and productivity, contributing to higher savings and investment, and the release of large amounts of labor for employment in emerging in them owner's lands. Reforms also began in other areas but were not as dramatic in scope or effect. Most notably, open economic exhibitions were organized by Ministry of Finance \&Economic to attract foreign investment and promote local production and maximizing trade, and to serve as PS for bolder market-oriented reforms. Tentative steps were taken to scale back the reorganizing system for public Ml's, and experiments were begun to link remunerations more closely to performance.

\subsection{2: Phase II: Broadening of reforms (after 2003-2009):}

One of the most important elements for openness policy is transition the KR from dependency region to attracting the foreign investment participation and 
contribution. The KR is sure in its national economy and the strength of the economic position related to the external world, for acceleration the social-economic development, due to comprehensive lack in some projects, for encouraging PS and foreign investment to provision of Kurds needs from different projects. In this realm, and to keep abreast with the international economic, walk with the new economic movement of thought, granting more facilities, incentives and the exemptions tax for investors, the KRG issued the special resolution No.89 in 17.3.2004 titling (The investment promotion law in Kurdistan Region) for the organization of various aspects in investment process in KR. In 2.7.2006, KRG has issued the investment law No.4 as a motivation to activate the national capital and the internal labor force's to revive the economic structure in KR.

KRs' positive factors to changes in development strategy are (KRG/Ministry of Planning): a) disciplined labor in neighbor-hood countries, b) the emergence of a more democratic political system creating conditions for creativity, c) more save region in Iraq, d) entrepreneurship, and e) KR has a hospitality society for foreign immigrating.

The non-success of rural reforms led to a gradual broadening of reforms, most notably to state Ml's in urban areas, and the gradual dismantling of the central planning system. Important measures included experiments to non-grant public manufacture more autonomy in production and employment decisions (the recruitment in governmental $\mathrm{Ml}^{\prime} \mathrm{s}$ ). In addition, private enterprises began to gain more importance than public enterprises. The trade and exchange system also began to be liberalized, and the foreign trade plan scaled back. Key measures included the establishment of "exhibition" for trading retained foreign exchange and the formation of local foreign trade corporations. The reforms helped to sustain and broaden growth following the earlier transition in agricultural production and led to the emergence of a dynamic PS. Difficulties in macroeconomic control, however, eventually gave rise to inflationary pressures, necessitating a tightening of macroeconomic policies. The late 2000s represented a period of "rectification" during which reforms were slowed or reversed in an effort to help re-establish macroeconomic stability. 
The preventing of exporting the raw material except petrol has a very good positive role on growing the MI's in KR. With noted that there are not many differences between the raw material market and secondary market in $\mathrm{KR}$, but many local raw materials did not used by local Ml's. For example in the period 2001-2005, the KRG had purchased the local tomato and sunflower...etc for using as raw material in Sumeel Dairy Production manufacture and in the manufacture of tomato in Harir, and due that its prices had going more and more expensive.

The elimination of legal impediments for investors, and to make wide investment for foreign \& local capital in projects were contributed actively in the economic development. Perhaps, the most important fear position is the issue of the right to own land for foreign companies that invest in KR and the law was not clear any attention to the dangers of ownership for example identify (within the need to conduct the licensed activity).However, this right for the first glance raises some concerns due to the geopolitics complexities in the situation of KR. The ownership of Kurd's land by foreign has been always a weapon of Kurds enemies in order to change the KR national reality as whole. However, it seems KR's political leadership has had another visions, based on other convictions remove these fears, and to beware of plans threaten the national security of KR.

Despite the KRG's effort to conduct several changes and evolution for the period 2005-2006 for KRs' development in different fields in particular in service sector and focusing in investment depend upon reconstruction in KR. However, it is not comprehensive for whole the region, where led to: i)ignoring of village, ii)the existence of huge proportion of villages or/and cities living in poor level, iii) lack of abundant of livelihood health in different area of $K R$, and iv) the appearance of a significant disparity between the urban and rural areas. That leads to the emergence of other economic problems, in addition to the disparity between population provinces themselves by emergence renewed rich for increasing the proportion of the poor, and increased unemployment, which led to an unequal distribution of per capita income in the KR. Therefore, the distribution of investments and economic activities on the different geographic areas as far as possible lead to redistribution of better income and improvement of the individual standard of living and increase of 
savings which is contributing to the other investments. That provides additional job opportunities that would increase the GDP of goods and services, thereby following into the region's economic growth.

The most important characteristic of this period compared to previous period is serious attempting for building and organization of Kurds economic and participation of PS in particular the foreign investment in order to build the economic base after collapse of economic structure of Baath regime and abolition a lot of resolution of that regime. Also it characterize by formation of council of economic planning, MoP, Investment Board and mixing the industry and commerce sectors in one ministry in order to make leadership, and encourage of PS for taking its role in contribution of achieving the ID, therefore it has developed the annual and five economic plan in KR.

\subsection{3: Phase III: Deepening of reforms (since 2010):}

The rectification program succeeded in reducing corruption at the expense of slower growth and a partial reversal of economic development. Following raising the citizen's discontent of corruption, services and his call for been a strong region in Iraq to accelerate reform, progress resumed with oil energy. Even nevertheless, KRs' inducement led to a boom in fixed investment and the reemergence of inflationary pressures, it culminated in a new reform policy, adopted during the sixth KRs' government cabinets by presidentially of Barham Ahmed Salih in 2010. The sixth KRG cabinet articulated the goal of continuing a market economy, within the context of continued dominant private ownership. A key focus of the policy was to strengthen the institutions and infrastructure for macroeconomic control and increase the market liberalization of the economy through wide ranging reforms of resolution in the education sector, the fiscal and trade system. In addition, the policy provided a framework for the acceleration of privatization of public Ml's reform.

Thereby, KRs' new ambitions have been formulated in short \& medium term in terms of economic strategy documents. In the 2011, the MoP drafted a paper entitled "RDS for Kurdistan Region 2012-2016". It describes three economic growth scenarios: a moderate one (the present model based on agriculture), maximum accelerated 
exploitation of raw materials, and finally, the creation of an economic model based on investment and knowledge.( KRG/ Ministry of Planning), 2011.)

Here, the economic reform as re-administration of economic sources and the new economic performance of government are the most necessity of this economic phase of $K R$, in particular the huge budget has gained the $K R$ a little seen a developing without directive economic plan which could be said it is an economic changing under the chaos and corruption. Nowadays, it should be the development administration re-checks its historic role by reform, because $K R$ facing the international openness until KR will arrive the satisfaction socially/economically situation and KR will be in the powerfully economic environment in the middle-east.

\section{2: First phase of the reform program of KR in 2011:}

Regarding first phase of the reform program of KR Presidency in Juin 2011 were been the following program (KR Presidency, March 2012)

\subsection{1: Firstly: including land allocation for investment obstacles:}

- Granting of all licenses for investment projects were stopped and all land allocations were ceased for a duration of two months, with the exception of current projects in the sectors of agriculture, industry and tourism which had international brand in order to organize the process of land allocation and the granting of licenses for investment project to increase transparency and fairness.

- The suspension of agricultural land extinguishing for 90 day, for purpose reauditing whole contracts conduct illegally in 4 last years ago (before 14.06.2011), and also for designing a new appropriate mechanism and regulation for future under the principle of law, public interest and region's development. (KRG, Board of Integrity)

- Regarding Musataha ${ }^{1}$, the whole contracts of Musataha mortised which expired them legal deadlines or didn't started yet, with take legal proceedings that contracts has expired them legal deadlines. Including Musataha projects, 118 contracts were

\footnotetext{
${ }^{1}$ An Arab word for usufruct right or/and legal right to build on and retain the building on another person's land for a fixed term of years or legal right to develop the land own by another person for a maximum period of 25 years.
} 
terminated in 2011, which included approximately 633 acres of land and returned to the government. A separate order was issued to terminate all land allocations to projects which had expired deadlines or whose implementation had not started for redistribution with principle of transparency and justice by legal competition and uses for public interest.

- Regarding administrative reforms in 2011, a number of senior KRG's officials have been dismissed. This is an ongoing process to ensure that only competent individuals will occupy positions within the KRG administration, but still were not enough.

\subsection{2: Secondly: Rule of Law:}

In order to improve the judiciary in the Region in 2011, a judicial institute was established to enhance the training and recruitment process of new judges. Judges will no longer be recruiting according to the old system or by political appointments. The individuals within the judicial sector need to attend the institute before receiving positions as judges.

Regarding the Integrity law, there were deliberations on new legislation to establish a Public Integrity Commission have begun in the Iraqi Kurdistan Parliament. In other side in 2011, also the KR Presidency recommended the Council of Ministers for establishing a council for the consumer protection.

It worth to mentioning the reform process is waste and multilateral by very important files, therefore the KR presidency promised to take a conduction of these files continually. It work for designing the transparency policy for contract and contracting sector and doing the continually follow up for recruiting and equal workforce opportunities.

As well as the KR presidency promise to check and follow up for market's monopoly, in this realm it should be work on the draft law of competition and prevent the monopolies phenomenon.

The researcher believes the reform process isn't to the extent of required but it is good stage for reforming the existence of powerfully will inside of political Presidency 
of KR, especially inside of president Masoud Barzani for conducting real supporting for reform and he is with fight against the corruption and usually he said: "I'm with changing and advancing the institution but please don't destroy it whole Kurdish obtaining and it have to save it". But he takes procedure as a macro not in micro. Where until 2011 especially before taking these procedures, the corruption was like an institution in the linkage of governance and its work conduct as institution in the blood.

Asjudge Azad Mala Fandi the chief of reform committee in KR Presidency for newspaper of Rudaw said: "there were been a mafia ${ }^{2}$ behind of this corruption and this corruption is accumulated in several years". ( Journal of Rudaw)

\section{3: The infrastructure of market trade in KR:}

The KRG attempts to address the economic situation for purpose to correctness the structural imbalance, the motivation of productivity capabilities in $K R$, with striving toward provision of local economic environment to developing launch with dimension of effective social concern in the private sector to activate its role in economic activity in one hand, and enhance the ability to motivate and attract domestic and foreign investments that generate new jobs. But these programs and policies have not succeeded to achieve high rates of economic growth to ensure the provision of adequate employment opportunities to absorb the large numbers of entrants to the job market every year. Despite the low unemployment rate, but they are in other type of unemployment which disguised unemployment is at high levels, and it is a real problem suffering the economy of the region.

The structural adjustment in KR include arrangement directly or non-directly impact on labor market such as privatization, the consequent on closing the institutions completely, winding up of a company and demobilization of its workforces. As well as caused to some political reform such as the policy of reduction of value from reducing

\footnotetext{
${ }^{2}$ Mafia here is not means a large organized group of criminals but large group monopole everything for them interests.
} 
the raw material, secondary and investment material, thereby reducing the volume of investment and disruption of machinery production, which have huge impact on the volume of labor that obligated the government to transferring the workforces in public manufacturing industries to the official administrative department that has led raising the disguised unemployment rate.

\section{1: Openness:}

It has to distinguish the enterprises in two kinds of enterprises for commercial and enterprises for industry. Who decide before 2003? Big player is government and discussion is inside of public not private sector.

The money distribution and ordering of budget consummation was centralized by Ministry of Finance and Economic and they decide all ordering as like as $1930^{\text {th }}$ in Russia. Sometime the Mol has decided amounted for one of them project but ministry of finance they could decrease the amounted as they want and sometime refuse whole the project.

Comparative institutional advantage:

- Industrial development is favored in SME's while service industries thrive in Large-scale enterprises.

- Within manufacturing industry:

a. SME's are specialized in businesses in which competitiveness is based on the accumulation of specific skill with innovation being created in increments.

b. Large-scale enterprises on the other hand are more likely to give rise to radical innovation, orienting specialization toward industries where reaction speed to market changes is a determining factor.

The main KR's commercial companies were listed on the stock exchange, and global financial fluctuations no longer spare Baghdad and Erbil. In addition, KR seeking Western-Eastern- Iranian-Turkish companies, exactly the Turkish companies. 
These factors are fueling new ambitions both internationally and domestically. Iraq has lost behind the crises of the 1990s and in general before 2003, and aims to take its economic and political place among developed countries and be competitive on the global stage. Competitiveness has become a watch word for Kurdish leaders in general and KR's leaders particularly. The countries opening up is seen both as an opportunity and as a challenge because of the accumulated economic lag and the "curse" that energy resources represent possibly condemning KR to the role of "World supplier of raw materials".

There are some economists and politicians believe: It must be avoid FDI and KR should not allow the integration of their economies with developed countries economies in several aspects because:

The exaggeration in the application of openness policy has caused to changing in different aspects of economic, politic, and social, even the economic changes were more noticeable and the embodiment compared to other aspects, but the researcher will try to shed light on very shortly on other aspects due to the overlapping side with the social aspects of economic, cultural and political.

The FDI has a risk on KR's economic in terms of its size and the diversity of its activities, whether industrial or agricultural or services and its installation requires from facilities draining more of its resources and its sovereign considerations especially since many multinational companies took the parts of the economies of the countries to which it belongs and its transformation into affiliates sections in the management of its branches in the world.

It's important to point out in this area to the rapid profits growth of these companies achieved by the impact of two factors; a) by raising the prices of their products in the markets in which monopolized, and b) by controlling the exports and imports of countries in which it operates and to the extent that leads to imbalance of payments. If it considers the strategies of multinational companies adopted in their investments in developing countries find that they are linked to the interests of political and 
economic countries to which it belongs. The investment do not include achieving developmental goals its results for service development plans and programs for these countries, just by the extent to which believes it relevant the economies of these countries. with that the researcher incredibly said previously, but also the researcher believes the presence of these multinational companies are necessary to achieve the objectives of the KR's supreme political because these kind of companies for the purpose of retaining their capital investment are forced to keep the KR's land of the challenges of other countries politically and sometimes they change their point of view of other countries because of their economic interests in the region and therefore the KR's authorities must be follow a little bit and premeditated policy of devotion of political - economic.

In sum, the global trend towards economic liberalization is comprehensive approach should to be accompaniment, but by minimal lost, because the next openness will have a lot of negative strongly effects on KR's small-scale economies, and the low ability to compete with the economies of the developed countries with large scale and huge competitive ability. Due to the KR's economy is small size, it will be affected negatively for not being able to compete and thus eliminating the emerging industries and exit from the next market.

\section{2: Market Trade Situation:}

The geographic conditions, excess of money supply together with the recent 9 years of comprehensive public investment programs in infrastructure have led to relatively high returns on investment in the region. Despite its positive effects in the creation of trust and security for investors, the mixture of politics and business is a cornerstone to the spread of corruption and the alliance is positively associated with the high level of tolerance of corruption. Over time it is reaches such a level that the state loses public trust and it gradually undermines the stability and the power itself. Increasing incomes, an expanding population and growing urbanization have led to a high consumption rate, which in turn has minimized the risks associated with business in the region, including the storage of large quantities of imported commodities. 
The most distinguishing feature of the $K R$ is being a commercial area mission has increased this importance after the second Gulf War, and the imposition of economic sanctions on Iraq, as it became an important outlet for KR's trade with Iraq, Iran, Syria and Turkey indirectly also the KRG benefited its location to the face of the siege imposed by the Iraqi central government moving to establish commercial relations with neighbouring countries to mitigate the impact of dual blockade of $K R$, foreign trade to become lifeline that created the reasons for success of the Kurdish administration in overcoming many of the problems.

Then, the program of IMF for economic stabilization focused on reducing the demand term in economic in short-term, and if this deflationary policy would address the trade deficit, the deficit budget and reducing the inflation rate. The programs of the World Bank structural adjustment is focusing on expanding the supply side of the medium-term to long-term, through the liberalization of imports and privatization and the removal of protection and support procedures. The stabilization program integrated with economic structural adjustment programs, whose need to get a structural adjustment loan that the country has implemented a program of economic stabilization.

As it clear from the data there are just the data about the imported commodities without the value of export commodities which the reason return to there aren't the number of exported in accounted except some raw material such as occasion of plastic and aluminum for purpose reprocessing, as well as the exportation of petroleum. It worth to mentioning the administration affair of costume is undertake the responsibility of Ministry of Finance and Economic, and the exportation of petroleum is undertake the responsibility of Ministry of Natural Resources. In the other side the increasing of imported commodities by Compound Annual Growth Rate (CAGR) $44.36 \%$ in 2010 comparing to 2007 return to the inabilities of local production for provision the consumer needs in KR.( KRG/ Ministry of Finance) In the other side it notes largest numbers of the goods value that are re-exported from region to Iraqi provinces and vice versa, and some are re-exported to Iran across the land of KR. 
It worth to mentioning the KRG did not allowed importing some agriculture production in the production seasons for protection the local production and encouraging the local firms for increasing the local production.

Regarding Iraqi attempting to been membership in the WTO the council minister presidency make a special group for studying how could be a membership in this organ and the chief of Union of Trade and Industry Room in KR "Mr. Dara Jalil Khayat" said: "KR is not dependence country and could not be a membership in WTO.... Even Iraq don't have needed condition for been membership for this matter the discussion of the committee for membership has stopped".

So, if KR integrates with WTO, there will have negative and positive effect on KR's economies, and researcher believes that the integration to WTO the KR's urged would decrease self-reliance in the provision of food and this could be only achieved through the promotion and development of the agricultural sector in this KR, according to a long-term time. But actually it refers to the low contribution of this sector in GDP and that it suffers from major problems and many obstacles.

It noted the number of Turkish companies recorded $38.63 \%$ of total foreign companies until 2009 while had arrived to $51.58 \%$ of total foreign companies in KR in 31.7.2011 where has increased its number very clearly by $50 \%$ of total foreign companies and its reason return to increase the good politic relation between KR and Turkey. Regarding the registering the companies in KR in the end of 2011 arrived to 13396 companies which $13.3 \%$ of them are foreign companies and $86.7 \%$ are local companies and Erbil province take the first place of foreign companies by $68.95 \%$. ( KRG/Ministry of Trade and Industry)

And if compare the registering of companies by year it could see, before 2010 it was 9166 companies which $11.54 \%$ of them was foreign companies and Erbil governorate take lion share of foreign companies by 60.4\%. But it could see in 2010 and 2011 registered around half of before this date by registering 4230 companies and it should be mentioned the rate of registering of foreign companies were increased $17.1 \%$ for 
mentioned period which it return to increasing the investment guaranties and securities in region and opening a lot of embassies and consultant of foreign countries, changing the investment environment mentality to openness, as well as increasing the investment activities...etc. as it clear from the data the Erbil governorate increased its registering in foreign companies' to $13.92 \%$ in $2010-2011$. (KRG/Ministry of Trade and Industry,2012)

\section{4: Marketing principle of government in KR:}

As Adam Smith sees the government to make the organization and discipline it have to organize the economic-social relation between the individuals in society. The private ownership has to take far from risks, and government should prepare assurance for citizen's private ownership. It's important for advancing the private ownership in society. With developing in this field, the citizen feel in responsibility on ownership, society and him/her nation in general. Democracy and free market pushing to pluralism, because there is authorities distribution between community and different organs in the society. (Wolfgang Merkel, 2014.)

In order to facilitate the transformation of the skills needed to adapt quickly to changing dynamics at the economy, the opportunity for studying at vocational and technical schools and institutions for these who want to acquire, develop or change profession has been further expanded. But have to mention there are some interaction administration working in this realm within the coordination of Ministry of Labor and Social Security, Ministry of Plan, ministry of education as well... organizations and institutions in the field of vocational and technical training.

The financial crisis which deteriorated after September 11, 2008, resulted in entering into to global recession period and the countries like Turkey is most evident are the developing countries which were not directly affected from the economic collapse, especially Turkey well find KR that begun early to development and they have a lot of sectors for investing such as airport, road, school and hospital building...etc. 
Even if $K R$, in its own way, tried to reduce the consequences of associated social and political for experiences of proposed structural adjustment by the international monetary institutions or for the experiences more focused on the keeping the greater premium than government intervention in economic regulation, but its success or failure is not associated only the economic regulation method technically, but more related to the existence of government institutions, popular representation and subject to the control and accountability, the things that lacking in the existing political systems the evidence is that ruling elites are primarily responsible for disabling the path of reforms, which are primarily responsible for the consecration of illegal economic practices.

Regarding the economic policy for industrial, as the industry and agriculture sectors are consider the backbone of economic structure, and KR's economic needs more time for depend on himself resulting to previous regimes system on it, which did not desire to the KR's development in economic aspect. However, after 2003 the KRG conducted some procedures for developing the industry sector, which regarding problem and obstacles of this sector the minister of industry in KRG "Widad Arsalan" in 2009 said: "The policy of the KRG in the field of industry built on the support of the private sector ...etc". But in other side the economist believed in order to lack of the industrial sector plan in KRG was in underdevelopment! And according the theory of some economist in KR, the achieved development in KR not have impact on KR's economies in future because almost of investment companies worked on the building field of housing, apartments, and other of real estate that are needed to essential services, so these projects did not turn out to unemployed workers to run and create jobs, or to find an industry!

Actually, the KR needs to long-term plan for development that consistent with the capabilities of material, technological and social. It worth to build or develop the economic sector at the expense of another sector, and KR is an agricultural region as well as provision all of industrial development requirements, and so far, except some manufacturing industries such as Cement and Iron there isn't have create any an important strategic industry in the KR. 
Here, it is raising another question, did have been allocated amounts in the KRG's investment budget for the development of the manufacturing industries private sector?

\section{Conclusion and suggestions:}

As all other developing countries in privatization experience, the privatization process has faced many problems and obstacles on proper applying program successfully in $\mathrm{KR}$. Thereby, the main roots of these problems are as below which shall to be working on it for solving:

n. Lack of legal document and popular supporting.

o. Lack of legal legislation to reducing the problem of unemployment.

p. The privatization has led to dispense of civil service of technical personnel in the areas that shifted from the public to the PS.

q. Lack of particular board for implementation of the privatization process for evaluation.

r. The technology obsolescence of machineries and equipment in public Ml's.

s. The $\mathrm{MoCl}$ that is implementing body for industrial privatization did not conduct the objective assessment for assets and machineries in public facilities.

t. The privatization did not provide added-value and surplus revenue for KR.

u. There are some public manufactures which did not privatize, because some of them did not has any revenue and some of them did not has consider in account production. It should be mentioned this manufactures despite they did not have production or have a low production while KRG obliged to pay the salaries of employees.

The economic reform as re-administration of economic sources and the new economic performance of government are the most necessity of this economic phase of $K R$, in particular the huge budget has gained the $K R$ a little seen a developing without directive economic plan which could be said it is an economic changing under the chaos and corruption. 
In KR, the Success of public private partnership in the form of B.O.T mainly depends upon a having the sound legal structure, political stability, government structure and their long term policies.

The structural adjustment in KR include arrangement directly or non-directly impact on labor market such as privatization, the consequent on closing the institutions completely, winding up of a company and demobilization of its workforces.

B.O.T contracts cannot be applied according to the current laws in Iraq, for there are many legal challenges which impede or obstruct performance them. Amongst the problems is the allocation of investment lands. Thus, Iraqi legislature must resolve this legislative weakness in order to attract and encourage the foreign investment in to the country.

In sum, the global trend towards economic liberalization is comprehensive approach should to be accompaniment, but by minimal lost, because the next openness will have a lot of negative strongly effects on KR's small-scale economies, and the low ability to compete with the economies of the developed countries with large scale and huge competitive ability. 


\section{REFERENCES:}

1 See:

a. Meervat Altaie, Paving the Way for PPP's to Infrastructure Projects in Iraq, The Journal of Engineering, 20(10):32-60 - December 2014, P.39. https://www.researchgate.net/publication/299343985 Paving the Way for PPP's to I nfrastructure Projects in Iraq.

b. Shiva Damyar and Khodadad Khodadadi Dashtaki, Legal Review of Impact of BOT Contracts on Economic Development in the Country, Revista Publicando, 4 No 12. (2). 2017, 621-639. ISSN 1390-9304.

\section{https://revistapublicando.org > revista > crv > article > download > pdf 874.}

c. Ministry of Planning, IRAQ RECONSTRUCTION and INVESTMENT, PART 1 Reconstruction and Development Framework, February 2018.

http://www.cabinet.iq/uploads/Iraq\%20Reconstruction/Iraq\%20Recons\%20\&\%20Inves. pdf

${ }^{2}$ Facts of Iraq, No.3090, Baghdad-Iraq, 1986, p.182.

${ }^{3}$ Razzaq OTHMAN MUSTAFA, Developing Economies, Evaluation of Manufacturing Industrial Development and a Model for Industrial Development for a Case of Kurdistan Region/Iraq, A Dissertation of Strategy of Industry/ Economic, CEMI-EHESS-Paris, France, 2014, 581.

${ }^{4} \mathrm{Gol} /$ Ministry of Planning and Development Cooperation, the National Development Plan for the years 2010 - 2014, Republic of Iraq, Baghdad, 2009, p.50.

${ }^{5}$ Conversation with:

a. Ministry of Trade and Industry, Directorate General of Administration and Finance, Directorate of Legal Affair, Data non-Published.

b. Ministry of Trade and Industry, Directorate General of Industrial Development, Directorate of Legal Affair, Data non-Published.

${ }^{6}$ Data from:

Ministry of Trade and Industry, Directorate General of Industrial Development, Directorate of Legal Affair, Data non-Published.

${ }^{7}$ Ministry of Planning, Report on industrial sector: The development of industrial activities in private sector 2002-2006. http://www.mop.gov.krd/index.jsp?sid=1\&id=146\&pid=105

${ }^{8}$ KRG, MoP, RDS for Kurdistan Region 2012-2016, Erbil, 2011. http://www.mop.gov.krd/resources/Strategic\%20Plan/PDF/spa.pdf 


\section{QALAAI ZANISTSCIENTIFIC JOURNAL \\ A Scientific Quarterly Refereed Journal Issued by Lebanese French University - Erbil, Kurdistan, Iraq}

Vol. (6), No (1), Winter 2021

ISSN 2518-6566 (Online) - ISSN 2518-6558 (Print)

${ }^{9}$ KR Presidency, Report of the Committee to follow up the reform project presented by the President of the Kurdistan Region, March 2012. http://previous.cabinet.gov.krd/a/d.aspx?s=010000\&l=14\&a=43386

${ }^{10} \mathrm{KRG}$, Board of Integrity, Directorate of Investigation, Non-Published paper.

11 Available in Journal of Rudaw in Kurdish language in: http://rudaw.net/kurdish/index.php/news/8274.html

${ }^{12}$ KRG, Ministry of Finance, Directorate General of Customs, Erbil, Non-Published data, 13 Available in site of journal of Rudaw in Kurdish language: http://rudaw.net/kurdish/index.php/aburi/16285.html

${ }_{14}$ Data from: KRG, Ministry of Trade and Industry, Directorate General of Company Registration, Non-Published data.

${ }^{15}$ Data from: KRG, Ministry of Trade and Industry, Directorate General of Planning, Annual report 2011, Feb 2012.

${ }^{16}$ See: Wolfgang Merkel, Is capitalism compatible with democracy?, Z Vgl Polit Wiss DOI 10.1007/s12286-014-0199-4, ESSAY, Springer Fachmedien Wiesbaden 2014. https://projects.iq.harvard.edu/files/mobilized contention/files/merkel is capitalism compatible with democracy.pdf

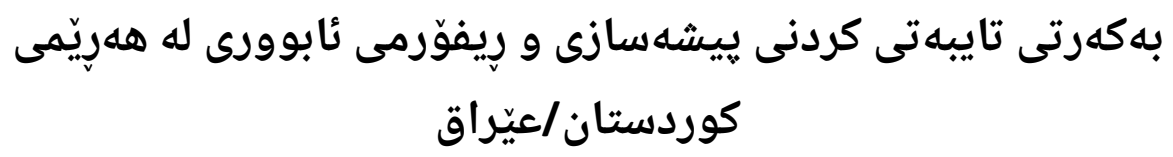

يهرهييّدان يِيّش سالّى 2003 له نهبوونى هلبووهكانى دهنالَاند به تايبهت ههبووهكانى دارايى. به

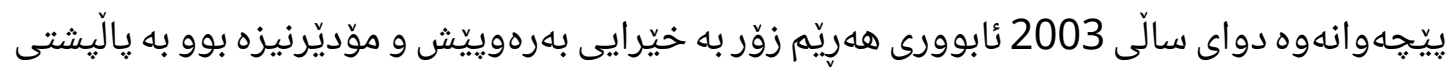
داهاتى نهوت، هاندانى كهرتى تايبهت، وهبهرهيّنانى سهرمايه، گه شهيِّدانى وهبهرهيِنانى رِاستهوخوّى بيانى FDI و بهكهرتى تايبهتى كردنى يروَزمكانى حكومى. تهدهخولى حكومهت له بازار هاته نزمترين

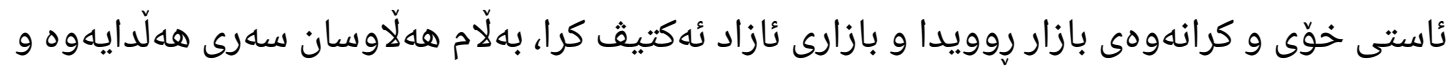
كريّيه كان بهرز بوونهوه و كهندهلى يهرهى سهند و رِكابهركيّى رِاستهقينه له ههنديّك كهرتهوه لاواز بوو و قوّرخكارى روويدا و ئهمه كاريكهرى نيّكيّنيقى لهسهر بهرهويِيش جوونى بهرههمى خوّمالى كرد. 


\section{QALAAI ZANISTSCIENTIFIC JOURNAL}

A Scientific Quarterly Refereed Journal Issued by Lebanese French University - Erbil, Kurdistan, Iraq

Vol. (6), No (1), Winter 2021

ISSN 2518-6566 (Online) - ISSN 2518-6558 (Print)

له ههمان كاتتدا بوّ رِخساندنى ههلى نوى ياساى نويّى وهبهرهيّنان (زماره 4ى سالّى 2006) له ههريّمى كوردستان داريّزرا و جيّبيجنى كرا. و دهبوا بايهخى تهواو و بنجينهيى به وهبهرهيّنان له زيّرخانى ئابوورى ههريم بدرابوايه. ليّرهدا جهند يرسياريّك ديّنه ئاراوه: ئايا زينكهى ئابوورى ههريمى كوردستان بوّ به كهرتى تايبهتى كردن به بهراورد له گلّ گهرهنتييه دستوورييهكان، ياسا كارييّكراوهكان و ريّنماييه كانى حكومهت بوّ كاركردن به شيّوهيه ريَّ ريّزهيى راهاتووه؟

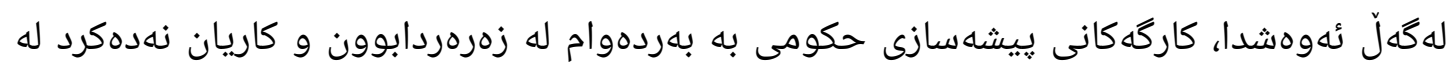

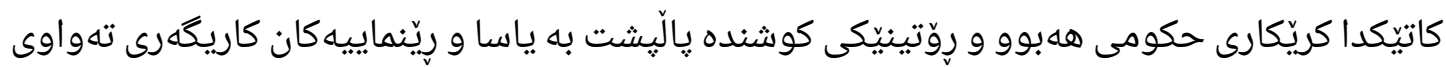
لهسهر بهرزكردنهوهى تيّجوون و بهبازارنهردنى شمهككان ههبووه. ههروهها بوّمان رووون بووهتهوه كه ههلى بهرهويِيش جوون له كاركه كانى حكومى ئيّكجار لاواز بووه و وهلامدانهوهى ئابوورييانهى نهبووه له روانكهى ئيدارهدان و داراييهوه به تايبهت به خهسارجوونى كات و ههولّلهان" وه ههوروهها ئيدارهدانى كهرتى حكومى كاركهكان و خوازيارى ياراستنى زياترى بهرههم و هاوكارى دارايى و سوبسيدايز بووه. لِّرهدا، نايا بهم شيّوازه رِيفوّرمى ئابوورى له ههرِيمى كوردستان رِوويداوه؟.

\section{خصخصة الصناعات التحويلية والإصلاح الاقتصادي في إقليم كوردستان / العراق}

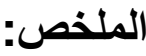

تتميز فترة التتمية في اقليم كوردستان قبل 2003 بعدم وجود الموارد الاقتصادية وخاصة المو ارد المالية. ولكن فئن

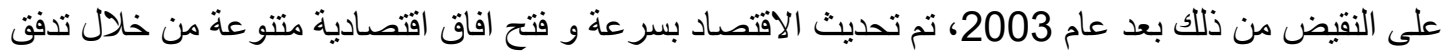

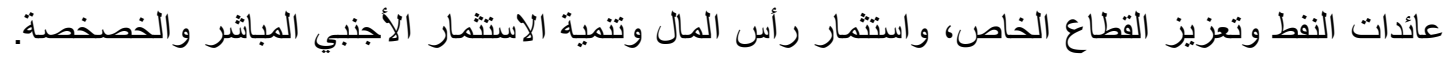

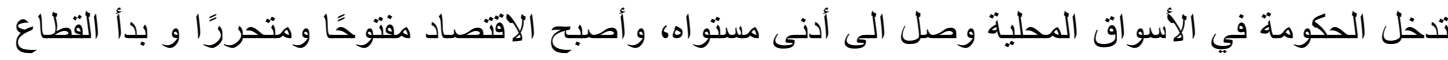

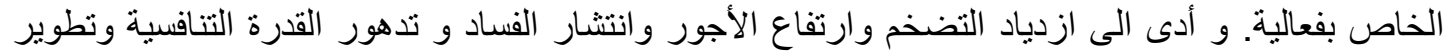
الإنتاج الصناعي المحلي. 


\section{QALAAI ZANISTSCIENTIFIC JOURNAL}

A Scientific Quarterly Refereed Journal Issued by Lebanese French University - Erbil, Kurdistan, Iraq

Vol. (6), No (1), Winter 2021

ISSN 2518-6566 (Online) - ISSN 2518-6558 (Print)

في الوقت نفسه، من أجل زيادة الفرص قامت الحكومة عن طريق السلطة التشريعية باصدار قانون الاستثمار

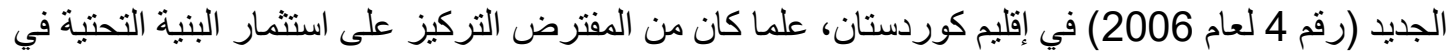

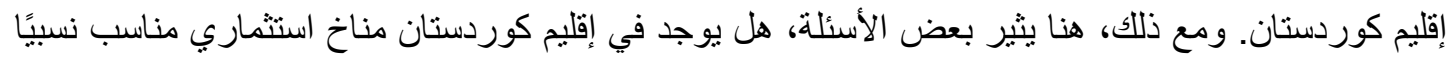

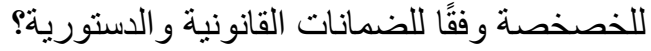

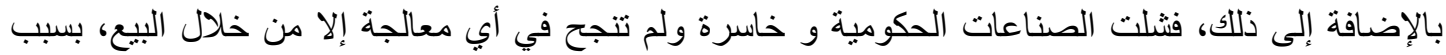

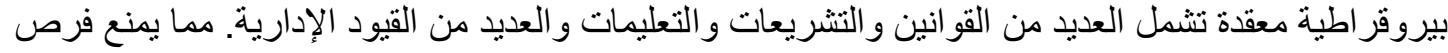

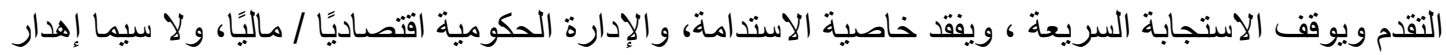

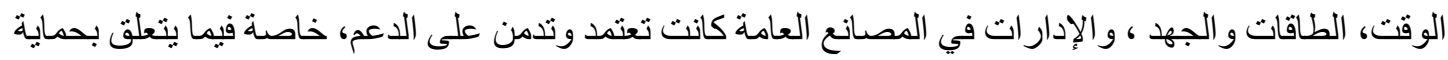

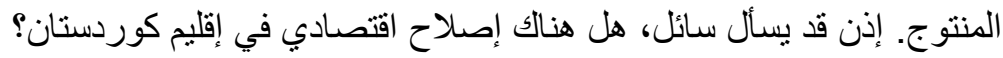

